\title{
IMPACT OF THE FORMER VINEYARD LAND USE ON THE PRODUCTIVITY OF SECONDARY FOREST HERB LAYER IN THE LITTLE CARPATHIANS (SW SLOVAKIA)
}

\author{
LUKÁŠ ZIMA ${ }^{1}$, JOZEF KOLLÁR ${ }^{2}$, IVANA VYKOUKOVÁ
}

\begin{abstract}
${ }^{1}$ Department of Soil Sciences, Faculty of Natural Sciences, Comenius University, Mlynská dolina B2, 842 15, Bratislava, Slovak Republic; e-mail: zima@fns.uniba.sk, vykoukova@fns.uniba.sk

${ }^{2}$ Institute of Landscape Ecology of the Slovak Academy of Sciences, Štefánikova 3, P.O. Box 254, 81499 Bratislava, Slovak Republic; e-mail: j.kollar@savba.sk
\end{abstract}

\section{Abstract}

Zima L., Kollár J., Vykouková I.: Impact of former vineyard land use on the productivity of secondary forest herb layer in the Little Carpathians (SW Slovakia). Ekológia (Bratislava), Vol. 35, No. 3, p. 253-262, 2016.

The Little Carpathians Mountains include a vineyard region with long tradition that dates back up to the Roman Empire period (and according to some opinions, even earlier). In the late $19^{\text {th }}$ century, it was strongly impacted by the phylloxera epidemic, and the vineyard area has significantly reduced here. Large areas of the former vineyards are covered by forests, which mostly have formed spontaneously, but some of them were also planted. This contribution is focused on the impact of the former vineyard land use on the productivity (aboveground, belowground, and total biomass) of such forest herb layer. Research included also the forests, which occupy rocky mounds formed by rock gathering and their placement on the vineyard borders. There were sampled by following four stands, mostly differed by tree composition, origin, age, and succession stage: (i) up to 100 years old spontaneously formed thermophilous acidophilous oak forest on the former vineyard on the granite substrate, (ii) up to 100 years old spontaneously formed oak-dominated forest on the rocky (granite) mounds (borders between the former vineyards formed by rock gathering), (iii) 40-60 years old planted ash stands on the gneiss bedrock, and (iv) 40-60 years old planted ash-dominated stands on the rocky (gneiss) mounds. According to our results, the former land use modified original relief, where the former vineyards have modified soil profile and new relief forms rocky mounds were created. These mounds with no or just shallow soils are usually much less covered by vegetation, thus production of herb layer biomass is lower here than in the adjacent former vineyards. Moreover, rocky mounds show a higher ratio of synanthropic species and apophytes than the adjacent former vineyards, and same as for ratio of therophytes. The younger the stands on the former vineyards, the higher is the ratio of synanthropic species, apophytes, and therophytes. On the other hand, when estimating the production quantity, the values of herb layer production on the former vineyards are similar to those in natural oak-hornbeam forests found in the Little Carpathians Mts. and the adjacent regions, except for the rocky mounds covered by old oak forests, which are less productive. In other words, the former vineyard land use affects the herb layer production quality rather than quantity.

Key words: forest, former vineyards, herb layer biomass, Little Carpathians. 


\section{Introduction}

Little Carpathians Mts. is a region with long viticultural tradition, which dates back to the $5^{\text {th }}$ century (Slavkovský, 2002) or even earlier - to $7^{\text {th }}-6^{\text {th }}$ century BC (period of Celtic culture) as evidenced by some artefacts (Záruba et al., 1985). The biggest boom of viticulture occurred between the $13^{\text {th }}$ and $19^{\text {th }}$ century. Viticulture strongly impacted landscape properties of the Little Carpathians. Except for deforestation and subsequent erosions, the sites of vineyards themselves were impacted by modification of the soil profile, which was performed by the deep ploughing prior to vineyard establishment. This practice involves overturning the soil horizons and moving the humus horizon to a depth of 40-60 cm where grapevines develop their best root system. Subsurface horizons (Bv or even C) with low humus content, coarser texture, and stones are then relocated to the surface as a result of this deep ploughing practice (Kolény, 2001; Dlapa et al., 2011). However, viticulture influenced also relief of direct vineyard surroundings - management practice included also rock gathering and its deposition into the special rocky mounds of various shapes and sizes. The viticulture boom was ended in the late $19^{\text {th }}$ century by the phylloxera epidemic. After this catastrophe, vineyards have not been fully restored any more. Nowadays, these former vineyards are mostly covered by forests, which mostly have formed spontaneously, but some of them were also planted. There can be distinguished several types of such forests differed by succession state, substrate, and former land use; their detailed phytocoenological and ecological characteristics are given in our previous study (Zima et al., 2015). These forests occupy sites, where Carpathian oak-hornbeam forests (Carici pilosae-Carpinenion suballiance) along with subacidophilous and thermophilous oak forests (Quercetum petraeae-cerris association) are considered to be potential vegetation (Michalko et al., 1986).

The aim of this paper is to evaluate the impact of the former vineyard land use on the primary production of the herb layer of the forest ecosystems, which are occurred here nowadays. Particular attention is paid to the ratio of synanthropic species, including apophytes and life forms, what can indicate site conditions and processes, for example, succession (Jurko 1990).

\section{Methods}

Estimation of the total herb layer biomass was carried out on the selected sample plots, applying the methods of indirect sampling (Kubíček, Brechtl, 1970) modified for non-recurrent sampling (Kubíček, Jurko, 1975; Kubíček, Šimonovič, 1975; Kubíček, Šomšák, 1982). Phytocoenological relevés were sampled according to the method of the Zurich-Montpellier school (Braun-Blanquet, 1964). Vascular plant nomenclature follows Marhold et al. (1998). Synanthropic species and apophytes were identified according to Jurko (1990) as well as life forms. However, life forms were simplified: shrubs and trees merged into the simple phanerophytes, annual and biennal species into the therophytes, herb and woody chamaephytes into simple chamaephytes; for species with more than one life form, which is more typical, was selected. The geographical coordinates are in the WGS 84 system. To compare the gathered data with those considered to represent the oak-hornbeam forests in the Little Carpathians and the adjacent regions, the following studies were used: Kubíček, Jurko (1975), Kubíček, Šimonovič (1975), Kubíček, Šimonovič (1980), Šomšák, Kubíček (1995), Kollár et al. (2009), and Kollár et al. (2010). The exact binomial test was used to prove whether the aboveground biomass in forests on the former vineyards (Ao) is lower than the aboveground biomass in the reference forests (Aref). Here, we tested whether the real probability of Ao<Aref is greater than the hypothesised probability of success in a Bernoulli experiment. 


\section{Characteristics of the study area}

Little Carpathians Mts are the westernmost part of the Carpathian arch with length about $100 \mathrm{~km}$ located in the south-western Slovakia (Lukniš, 1972). The highest point is the Záruby peak with its $768 \mathrm{~m}$ a. s. 1., but most of study sites are close to $300 \mathrm{~m}$ a. s. 1. The south-western part is formed by a crystalline core bordered by Mesozoic cover, while the north-western part is typical by Mesozoic Choč and Nedzev nappes (Fusán, 1972). The lower parts are classified as warm climatic regions, while the higher parts represent mildly warm climatic regions. The annual precipitation is mostly $600-700 \mathrm{~mm}$, but it can reach up to $800 \mathrm{~mm}$ in the high parts (Lapin et al., 2002).

\section{Characteristics of the sampled plots}

1. Horné Orešany, rocky mound (former vineyard border) adjacent to the next site, 40-60 years, area $6 \times 30 \mathrm{~m}$, cover: $\mathrm{E}_{3} 70 \%, \mathrm{E}_{1} 60 \%$, height of $\mathrm{E}_{3}$ : up to $20 \mathrm{~m}$, gneiss substrate, 21.5.2015.

$\mathrm{E}_{3}$ : Fraxinus excelsior 3, Cerasus avium 1, Quercus petraea agg. 1, Tilia cordata 1, Tilia platyphyllos 1 $\mathrm{E}_{1}$ : Alliaria petiolata 3, Melica uniflora 3, Fallopia convolvulus 1, Galium aparine 1, Veronica hederifolia agg. 1, Acer campestre +, Ace platanoides +, Cerasus avium + , Euonymus verrucosus +, Fraxinus excelsior +, Geum urbanum +, Polygonatum multiflorum + , Ligustrum vulgare $\mathrm{r}$

2. Horné Orešany, former vineyard, 40-60 years old forest dominated by ash, south-eastern slope $15^{\circ}, \mathrm{N} 48^{\circ} 27^{\prime} 32.3^{\prime \prime}$ $\mathrm{E} 17^{\circ} 25^{\prime} 21.1^{\prime \prime}$, area $10 \times 20 \mathrm{~m}$, cover: $\mathrm{E}_{3} 65 \%, \mathrm{E}_{2} 5 \%, \mathrm{E}_{1} 95 \%$, height of $\mathrm{E}_{3}: 20 \mathrm{~m}$, gneiss substrate, 21.5.2015.

$\mathrm{E}_{3}$ : Fraxinus excelsior 4, Quercus petraea agg. 2, Acer pseudoplatanus +

$\mathrm{E}_{2}$ : Corylus avellana + , Crataegus monogyna + , Malus sylvestris + , Sorbus torminalis +

$\mathrm{E}_{1}$ : Melica uniflora 5, Alliaria petiolata 2, Galium aparine 2, Poa nemoralis 2, Veronica hederifolia agg. 2, Fraxinus excelsior 1, Lamium purpureum 1, Acer pseudoplatanus +, Anthriscus cerefolium +, Bromus sterilis + , Carex muricata agg. +, Cerasus avium +, Geum urbanum +, Euonymus europaeus +, Euonymus verrucosus +, Fallopia convolvulus +, Mycelis muralis +, Polygonatum multiflorum +, Quercus petraea agg. +, Rosa canina agg. +, Stellaria media agg. +, Vicia sativa +, Viola odorata +, Acer campestre $\mathrm{r}$, Acer platanoides $\mathrm{r}$, Geranium robertianum $\mathrm{r}$, Malus sylvestris $\mathrm{r}$, Ulmus minor $\mathrm{r}$, Xanthoxalis stricta $\mathrm{r}$

3. Limbach, rocky mound adjacent to the next plot (former vineyard), up to 100 years oak trees with admixture of other species about 40 years old, southern slope $5^{\circ}, \mathrm{N} 48^{\circ} 18^{\prime} 11.3^{\prime \prime} \mathrm{E} 17^{\circ} 14^{\prime} 01.5^{\prime \prime}$, area $50 \times 30 \mathrm{~m}$, cover: $\mathrm{E}_{3} 65 \%$, $\mathrm{E}_{1} 30 \%, \mathrm{E}_{0} 10 \%$, bare rock $30 \%$, height of $\mathrm{E}_{3}$ : up to $20 \mathrm{~m}$, granite, trees prefer edge of the mound except for lime, 18.6.2015.

$\mathrm{E}_{3}$ : Quercus petraea agg. 4, Tilia cordata 1, Carpinus betulus 1 , Sorbus torminalis + $\mathrm{E}_{1}$ : Melica uniflora 2, Poa nemoralis 2, Urtica dioica 2, Mycelis muralis 1, Alliaria petiolata +, Brachypodium sylvaticum +, Carpinus betulus +, Erechtites hieracifolius +, Fallopia convolvulus +, Hedera helix +, Quercus petraea agg. ,+ Rosa canina agg. + , Rubus fruticosus agg. +, Tithymalus cyparissias + , Atropa bella-dona $\mathrm{r}$, Dryopteris filix-mas $\mathrm{r}$

4. Limbach, former vineyard, up to 100 years old oak forest, southern slope $10^{\circ}, \mathrm{N} 48^{\circ} 18^{\prime} 11.7^{\prime \prime} \mathrm{E} 17^{\circ} 14^{\prime} 00.0^{\prime \prime}$, area 10 $\times 20 \mathrm{~m}$, cover: $\mathrm{E}_{3} 65 \%, \mathrm{E}_{1} 75 \%, \mathrm{E}_{0} 2 \%$, height of $\mathrm{E}_{3}: 20 \mathrm{~m}$, granite substrate, 18.6.2015.

$\mathrm{E}_{3}$ : Quercus petraea agg. 4

$\mathrm{E}_{1}$ : Melica uniflora 4, Poa nemoralis 2, Fallopia convolvulus 1, Ajuga reptans + , Alliaria petiolata + , Brachypodium pinnatum +, Calamagrostis arundinacea + , Calamagrostis epigejos + , Hedera helix + , Tithymalus cyparissias + , Urtica dioica +, Quercus petraea agg. +, Veronica chamaedrys +, Acer pseudoplatanus r, Vicia hirsuta r, Campanula persicifolia r, Carpinus betulus r, Cerasus avium r, Dryopteris filix-mas r, Mycelis muralis r, Prunus spinosa r, Rosa canina agg. r, Rubus fruticosus agg. r, Stellaria media agg. r, Veronica officinalis $\mathrm{r}$

5. To illustrate the successionally most advanced stands (the most resembling 'climax'), this is a sample of thermo- and subacidophilous type of oak-hornbeam forests of Carici pilosae-Carpinetum association in the Little Carpathians relatively close to our plots published by Kubíček, Šimonovič (1980): 
Pezinok-Pezinská Baba, $300 \mathrm{~m}$ a. s. 1., the lower part of the $15^{\circ} \mathrm{SW}$ slope, over 100 years old, height of $\mathrm{E}_{3} 22-24$ $\mathrm{m}$, covers of $\mathrm{E}_{3}: 75 \%, \mathrm{E}_{2}: 5-10 \%, \mathrm{E}_{1}: 100 \%$, area $40 \times 50 \mathrm{~m}$

\begin{abstract}
$\mathrm{E}_{3}:$ Quercus petraea 4
$\mathrm{E}_{2}$ : Tilia cordata 1.1, Cornus mas 1.1, Quercus petraea +, Carpinus betulus +, Cerasus avium +, Acer campestre + , Fraxinus excelsior + , Fagus sylvatica + , Corylus avellana + , Crataegus laevigata +

$\mathrm{E}_{1}$ : Poa nemoralis 3.3, Melica uniflora 2.3, Carex pilosa 2.2, Luzula luzuloides 2.2, Dactylis polygama 2.2, Brachypodium sylvaticum 2.2, Galium odoratum 2.2, Melampyrum pratense 2.2, Festuca heterophylla 1.2, Bromus ramosus 1.2, Sanicula europaea 1.2, Melittis melissophyllum 1.1, Pulmonaria officinalis 1.1, Prenanthes purpurea 1.1, Fragaria moschata 1.1, Rubus hirtus 1.1, Mycelis muralis 1.1, Scrophularia nodosa 1.1, Cephalanthera rubra 1.1, Clinopodium vulgare 1.1, Quercus petraea 1.1, Carpinus betulus 1.1, Fraxinus excelsior 1.1, Cornus mas 1.1, Galium mollugo +.2, Dryopteris filix-mas +.2 , Geum urbanum +, Campanula persicifolia +, Viola reichenbachiana + , Impatiens parviflora + , Lathyrus vernus + , Lathyrus sylvestris + , Stachys sylvatica + , Hieracium murorum + , Digitalis grandiflora + , Rubus idaeus + , Tithymalus amygdaloides + , T. cyparissias + , Veronica chamaedrys + , Campanula trachelium +, Tilia cordata +, Crataegus laevigata +, Acer campestre +, A. platanoides + , A. pseudoplatanus + , Clematis vitalba + , Hypericum perforatum + , Rosa canina + , Geranium robertianum + , Cardamine impatiens +, Cerasus avium +, Sorbus aria +, Epilobium montanum +, Alliaria petiolata +, Galium schultesii +, Astragalus glycyphyllos + , Sorbus torminalis +
\end{abstract}

Such floristic composition of the herb layer well illustrates more-less natural forests of the area (e. g., Michalko et al. 1986).

\title{
Results and discussion
}

\section{Primary production of the herb layer of the forests formed on the former vineyard sites}

The basic results of the production-ecological analysis obtained from the four sample plots that represent typical forests on the former vineyards in the region of the Little Carpathians are summarised in Table 1. It contains the following information: type of the forest community, the abovebelow-total herb layer biomass (A, B, T) in kg.ha-1 ${ }^{-1}$ and a ratio above-belowground biomass (A/B).

In relatively young ash-dominated forest on the rocky mound (plot 1), synanthropic herb Alliaria petiolata prevail (A - $368.83 \mathrm{~kg} \cdot \mathrm{ha}^{-1}, \mathrm{~B}-13.23 \mathrm{~kg} \cdot \mathrm{ha}^{-1}, \mathrm{~T}-382.06 \mathrm{~kg} \cdot \mathrm{ha}^{-1}$ ), while Melica uniflora is the second most productive species (A - 133.93 kg.ha-1, B - 32.52 kg.ha ${ }^{-1}, \mathrm{~T}-166.45$ kg.ha-1 $)$. Other species are much less productive. This plot shows the highest ratio of synanthropic species (A - 70.36\%, B - 22.26\%, T-65.24\%). With this, the highest ratio of therophytes is related (A $-73.55 \%, \mathrm{~B}-22.73 \%, \mathrm{~T}-68.15 \%)$ - this is the only site where this life form prevails (high biomass of Alliaria petiolata). The ratio of apophytes is much lower (A - 3.19\%, B - 0.47\%, T $2.90 \%)$.

The adjacent ash-dominated stand on the former vineyard (plot 2) shows the highest production (A - 754.24 kg.ha $\left.{ }^{-1}, \mathrm{~B}-669.70 \mathrm{~kg} \cdot \mathrm{ha}^{-1}, \mathrm{~T}-1423.91 \mathrm{~kg} \cdot \mathrm{ha}^{-1}\right)$. The reason is that this forest represents younger succession stage, where the species composition is made of both natural and synanthropic species. However, grasses are still the most productive species. Of them, Melica uniflora is a leading species again (A - 521.14 kg.ha $\left.{ }^{-1}, \mathrm{~B}-606.67 \mathrm{~kg} \cdot \mathrm{ha}^{-1}, \mathrm{~T}-1127.81 \mathrm{~kg} \cdot \mathrm{ha}^{-1}\right)$ and Poa nemoralis is the second most productive species (A - $63.68 \mathrm{~kg} \cdot \mathrm{ha}^{-1}, \mathrm{~B}-29.60 \mathrm{~kg} \cdot \mathrm{ha}^{-1}, \mathrm{~T}-93.28$ $\left.\mathrm{kg} \cdot \mathrm{ha}^{-1}\right)$. Grasses together represent almost half of the total biomass. For this site, it was found as the second highest ratio of synanthropic species (A - 13.35\%, B - 0.75\%, T - 7.42\%). Apophytes are the least represented $(\mathrm{A}-8.67 \%, \mathrm{~B}-3.21 \%, \mathrm{~T}-6.10 \%)$. Of the life forms, hemicryptophytes 
prevail and also therophytes are an important biomass component. The ratio of other life forms is negligible.

The herb layer biomass of the old oak forest on the rocky mound (plot 3) was found to be the lowest (A - $196.60 \mathrm{~kg} \cdot \mathrm{ha}^{-1}, \mathrm{~B}-153.20 \mathrm{~kg} \cdot \mathrm{ha}^{-1}, \mathrm{~T}-349.80 \mathrm{~kg} \cdot \mathrm{ha}^{-1}$ ), which reflects harsh conditions for vascular plants on the rocky mound with no or very weakly developed soil. The most productive species here is Urtica dioica (A - $71.99 \mathrm{~kg} \mathrm{ha}^{-1}, \mathrm{~B}-58.07 \mathrm{~kg} \cdot \mathrm{ha}^{-1}, \mathrm{~T}-130.07 \mathrm{~kg} \cdot \mathrm{ha}{ }^{-1}$ ), which is almost $40 \%$ of the total biomass. Grasses Melica uniflora (A - $63.19 \mathrm{~kg} . \mathrm{ha}^{-1}, \mathrm{~B}-14.78 \mathrm{~kg}^{\mathrm{ha}} \mathrm{h}^{-1}$, T - 77.97 kg.ha-1) and Poa nemoralis (A - 51.30 kg.ha-1, 74.05 kg.ha $^{-1}, 125.36$ kg.ha ${ }^{-1}$ ) are the co-dominant species; their mutual ratio on the total biomass is almost $60 \%$. The ratio of synanthropic species is low (under 1\%), but on the other hand, apophytes (especially Urtica dioca) are an important component here (A - 36.6\%, B - 37.9\%, T - 37.2\%). In both oak forests, hemicryptophytes are the absolutely dominant species.

The adjacent old oak forest (plot 4) on the former vineyard is typical by a high production of grass Melica uniflora, which is decisive dominant species here - its ratio is about $90 \%$ of the total biomass (A - $441.64 \mathrm{~kg} \cdot \mathrm{ha}^{-1}$, B - $466.77 \mathrm{~kg} \cdot \mathrm{ha}^{-1}$, T - $908.41 \mathrm{~kg} \cdot \mathrm{ha}^{-1}$ ). The production of other species is more-less negligible, a bit higher values are reached only by Urtica dioica (A - 24.56 kg.ha-1, B - 9.89 kg.ha- ${ }^{-1}$, T - 34.45 kg.ha ${ }^{-1}$, Brachypodium sylvaticum (A - 20.61 kg.ha-1 , B - 17.50 kg.ha-1,

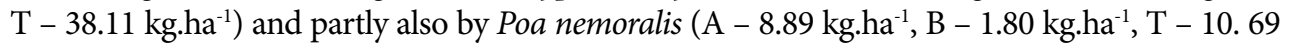
kg.ha- ${ }^{-1}$ ). Thus, grasses together represent over $93 \%$ of the herb layer production here. The ratio of synanthropic species is very low $(\mathrm{A}-0.46 \%, \mathrm{~B}-0.06 \%, \mathrm{~T}-0.26 \%)$ and also apophytes are only minor $(\mathrm{A}-5.02 \%, \mathrm{~B}-2.01 \%, \mathrm{~T}-3.52 \%)$.

\section{Comparison of the observed sites with the reference site}

The floristic composition of the reference forest representing the climax is not the same as in the observed sites, which represents the various stages of succession. It comprises different species with different ecological characteristics, and it is richer in species. So, there can be expected also some differences in the biomass quantity and quality. The biomass production is higher than those in the observed sites (A - $\left.1385 \mathrm{~kg} \cdot \mathrm{ha}^{-1}, \mathrm{~B}-1463 \mathrm{~kg} \cdot \mathrm{ha}^{-1}, \mathrm{~T}-2848 \mathrm{~kg} \cdot \mathrm{ha}^{-1}\right)$, and it has a different structure. There is a difference in the ratio of synanthropic species and apophytes (Fig. 2) - the younger the forest, the higher is the ratio of synanthropic species and apophytes, which complies with general patterns of succession. Moreover, forests on the rocky mounds show higher biomass of synanthropic species and apophytes than the adjacent forests on the former vineyards of the same age. This can be explained by the characteristic of the rocky mounds - it resembles ravine-like habitats suitable for nitrophytes, including synanthropic species and apophytes, and it represents a relatively young successional stage. When studying the ratio of plant life forms, a high ratio of therophytes in young forests is distinct, especially on the rocky mounds (A - 73.55\%, B - 22.73\%, T - 68.15\%), where a major role is played by Alliaria petiolata, while other sites are dominated by hemicryptophytes (Fig. 3). The reference site biomass also shows more even distribution - there is a higher number of biomass co-dominants (Luzula luzuloides, Melica uniflora, Poa nemoralis, Dactylis glomerata, Sanicula europaea), while the observed sites (especially the former vineyards) are dominated by only one or two species (Melica uniflora, Alliaria petiolata). 


\begin{tabular}{|c|c|c|c|c|c|c|c|c|c|c|c|c|c|c|c|c|c|c|c|c|c|c|c|c|c|c|c|c|c|}
\hline \multirow{4}{*}{ 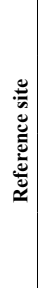 } & \multirow{4}{*}{ 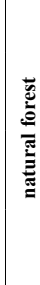 } & $\stackrel{m}{4}$ & $\stackrel{\infty}{\infty}$ & 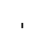 & ' & $\stackrel{\circ}{-}$ & $\hat{\mathrm{i}}$ & $\stackrel{0}{-}$ & oे & ' & . & ' & ' & ' & & $\hat{o}$ & 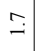 & $\stackrel{\circ}{-}$ & & & ' & ' & & ' & & ' & & & \\
\hline & & $t$ & $\dot{\vec{q}}$ & & 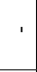 & 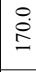 & $\begin{array}{c}0 \\
\dot{\dot{\alpha}} \\
\end{array}$ & $\begin{array}{l}\stackrel{\circ}{\dot{R}} \\
\end{array}$ & 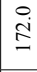 & & ' & ' & . & 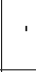 & & 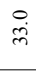 & $\stackrel{0}{\dot{\leftrightarrow}}$ & $\stackrel{\circ}{-}$ & & & ' & & & & & ' & & & \\
\hline & & $\infty$ & $\stackrel{+}{+}$ & & ' & $\begin{array}{c}0 \\
\infty \\
\infty\end{array}$ & 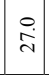 & $\begin{array}{l}\stackrel{0}{\dot{m}} \\
\text {. }\end{array}$ & $\stackrel{\circ}{\circ}$ & & ' & ' & & & & $\stackrel{\circ}{\Xi}$ & $\stackrel{8}{\circ}$ & $\begin{array}{l}n \\
0\end{array}$ & & & ' & & & & & & & & \\
\hline & & 4 & व & & ' & $\begin{array}{l}\stackrel{0}{\infty} \\
\infty\end{array}$ & $\begin{array}{l}0 \\
\dot{6}\end{array}$ & $\begin{array}{l}\stackrel{0}{\dot{f}} \\
\dot{F}\end{array}$ & 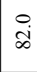 & & ' & ' & & ' & & $\stackrel{\circ}{\dot{I}}$ & $\stackrel{\circ}{\dot{\Xi}}$ & $n$ & & & ' & ' & & ' & & & & & \\
\hline \multirow{4}{*}{ 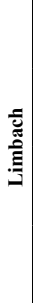 } & & $\frac{m}{4}$ & $\stackrel{\circ}{-}$ & $\stackrel{3}{i}$ & $\exists$ & $\vec{f}$ & $\cong$ & $\tilde{c}$ & $\overrightarrow{\mathrm{j}}$ & ' & ' & ' & $\stackrel{\infty}{\rightarrow}$ & $\stackrel{\Xi}{-}$ & $\stackrel{\sim}{i}$ & & & ' & & & ' & & & & & ' & & $\stackrel{+}{-}$ & $\stackrel{\circ}{i}$ \\
\hline & 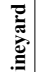 & $r$ & $\begin{array}{c}+ \\
\stackrel{\infty}{0} \\
\stackrel{2}{0}\end{array}$ & $\because$ & I & $\hat{\stackrel{\theta}{\Theta}}$ & $\mid \begin{array}{c}-\vec{\infty} \\
\infty\end{array}$ & $\tilde{\sim}$ & ชี & & ' & ' & $g$ & $\beth$ & $\stackrel{n}{\stackrel{n}{m}}$ & & & 1 & ' & & ' & & & & & & $\dot{0}$ & $\stackrel{0}{0}$ & $\vec{i}$ \\
\hline & 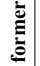 & 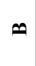 & $\begin{array}{l}\infty \\
\dot{0} \\
\vdots \\
\vdots\end{array}$ & $\overrightarrow{0}$ & ฮี & $\stackrel{\infty}{-}$ & $\stackrel{n}{\leftrightharpoons}$ & $\because$ & $\overrightarrow{0}$ & ' & ' & ' & 3. & ó & 2 & ' & & ' & 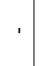 & & ' & & & & & ' & ชี & 3 & $\hat{o}$ \\
\hline & & $\varangle$ & $\begin{array}{l}0_{0} \\
\dot{F}\end{array}$ & ? & $\stackrel{\circ}{i}$ & $\dot{\infty}$ & 号 & $\hat{\circ}$ & $\overrightarrow{0}$ & & ' & ' & $\stackrel{0}{0}$ & $\stackrel{\circ}{-}$ & $\stackrel{0}{\stackrel{0}{d}}$ & & & ' & ' & & ' & . & & ' & & ' & $\because$ & $\stackrel{t}{\circ}$ & $\stackrel{ \pm}{-}$ \\
\hline \multirow{4}{*}{ 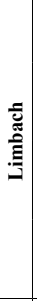 } & & $\frac{m}{4}$ & $\stackrel{?}{+}$ & 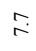 & $\stackrel{+}{+}$ & $\hat{o}$ & $\stackrel{P}{+}$ & $\stackrel{3}{0}$ & $\stackrel{n}{m}$ & ' & ' & ' & o & $\hat{o}$ & $\stackrel{\sim}{工}$ & ' & ' & $\stackrel{\circ}{-}$ & ' & & . & ' & & ' & & 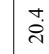 & & & \\
\hline & & $r$ & $\begin{array}{l}0 \\
\stackrel{\infty}{\infty}\end{array}$ & $\cong$ & 3 & वें & $\begin{array}{l}n \\
i \\
\end{array}$ & $\stackrel{\circ}{-}$ & t. & ' & ' & ' & लु & $\partial \dot{\partial}$ & $\ddot{g}$ & & & 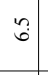 & ' & & ' & ' & & ' & & $\overrightarrow{0}$ & & & \\
\hline & & $\infty$ & $\stackrel{\infty}{ \pm}$ & $\stackrel{1}{\circ}$ & $\overrightarrow{0}$ & $\vec{I}$ & $\begin{array}{l}n \\
0\end{array}$ & $\hat{\circ}$ & $\overrightarrow{0}$ & & . & . & $=$ & 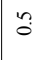 & $\vec{\infty}$ & & & $\begin{array}{l}0 \\
\stackrel{i}{i}\end{array} \mid$ & ' & & ' & ' & & & & $\stackrel{\circ}{\circ}$ & & & \\
\hline & & 4 & 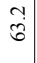 & $\because$ & รี & $\frac{m}{n}$ & $\stackrel{i}{i}$ & รี & 3 & ' & . & ' & 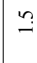 & t. & $\underset{\mathrm{i}}{\mathrm{i}}$ & ' & & $\stackrel{\circ}{+}$ & & & . & ' & & & & $\because$ & ' & & \\
\hline \multirow{4}{*}{ 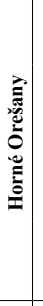 } & & $\frac{m}{2}$ & 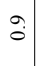 & $\Leftrightarrow$ & $\stackrel{\circ}{\infty}$ & $\tilde{N}$ & ' & ' & ' & $\stackrel{t}{\circ}$ & $\overrightarrow{\mathrm{S}}$ & $\begin{array}{l}0 \\
\infty \\
i\end{array}$ & & ' & ' & 9 & $\stackrel{\oplus}{-}$ & ' & 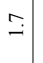 & $\stackrel{?}{\rightarrow}$ & t. & $\overrightarrow{\mathrm{I}}$ & $\because: 3$ & $\underset{I}{I}$ & $\begin{array}{c}y \\
c\end{array}$ & & & & \\
\hline & & H & 交 & $\begin{array}{l}\dot{0} \\
\stackrel{\infty}{m}\end{array}$ & $\overrightarrow{0}$ & హू & ' & . & ' & $\stackrel{+}{+}$ & $\begin{array}{l}\infty \\
\dot{m} \\
m\end{array}$ & $\ddot{q}$ & & ' & ' & $\stackrel{t}{0}$ & $\begin{array}{c}n \\
\dot{\alpha} \\
\alpha \\
d\end{array}$ & . & 3 & కె & 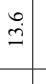 & : & $\stackrel{f}{\dot{f}}=$ & i & $=8$ & & & & \\
\hline & & 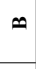 & 它 & $\stackrel{\circ}{-}$ & $\stackrel{\circ}{\circ}$ & 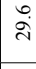 & . & . & ' & $\vec{m}$ & $\because$ & $\stackrel{?}{-}$ & & ' & & $\overrightarrow{0}$ & in & ' & $\overrightarrow{0}$ & $\overrightarrow{0}$ & 2 & $n$ & $\stackrel{m}{m}$ & \begin{tabular}{c|c}
\multirow{2}{*}{} & 2
\end{tabular} & 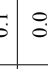 & . & ' & & \\
\hline & & 4 & $\overrightarrow{\dot{\sim}}$ & $\vec{m}$ & $\overrightarrow{0}$ & $\ddot{\hat{b}}$ & ' & . & . & $\stackrel{?}{9}$ & $\frac{m}{m}$ & $\stackrel{\infty}{q}$ & & & & ฮี & $\begin{array}{l}\stackrel{0}{\dot{b}} \\
\dot{\sim}\end{array}$ & ' & కి & $=$ & $\stackrel{\infty}{\exists}$ & $\vec{b}$ & $\stackrel{\sim}{:}$ & $\overrightarrow{\mathrm{i}}$ & $\begin{array}{lll}8 \\
8\end{array}$ & 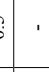 & ' & & \\
\hline \multirow{4}{*}{\multicolumn{2}{|c|}{ 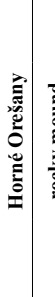 }} & 8 & $\bar{f}$ & $\stackrel{\vec{\lambda}}{\vec{\lambda}}$ & 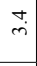 & & ' & . & ' & $\because$ & 官 & & & & & & & , & & & ' & & & ' & & & & & \\
\hline & & 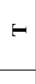 & 尊 & $\underset{ల}{i}$ & $\hat{i}$ & & ' & . & ' & $\bar{\Xi}$ & $\stackrel{+}{ \pm}$ & $\stackrel{\vec{H}}{n}$ & & & & & & ' & ' & & , & ' & & . & & & ' & & \\
\hline & & 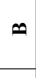 & in & $\stackrel{\sim}{\beth}$ & $\stackrel{\circ}{\circ}$ & & . &. & & $\stackrel{\leftrightarrow}{\circ}$ & $\tilde{0}$ & 3 & & ' & & ' & & ' & ' & & . & & & ' & & & & & \\
\hline & & 4 & 7 & $\begin{array}{l}\infty \\
0 \\
0 \\
\infty \\
\infty\end{array}$ & - & & . & ' & & $\stackrel{\stackrel{\leftrightarrow}{\sim}}{ }$ & $\vec{\Xi}$ & $\overrightarrow{i n}$ & & & & & & I & & & , & & & ' & & & & & \\
\hline & 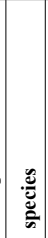 & 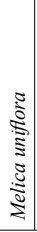 & 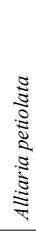 & 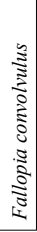 & 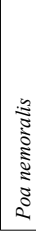 & 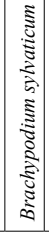 & 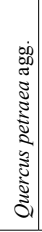 & है & 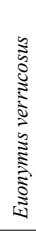 & 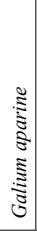 & 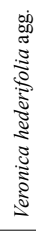 & 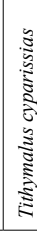 & 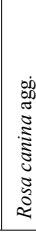 & 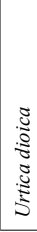 & 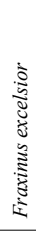 & 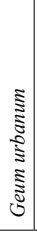 & 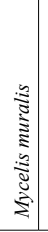 & 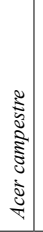 & 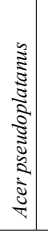 & 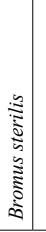 & 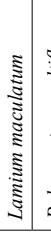 & 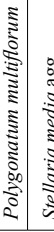 & 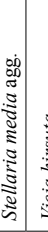 & 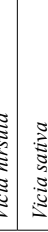 & 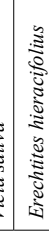 & 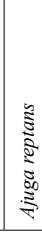 & 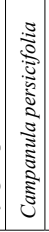 & 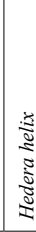 \\
\hline
\end{tabular}




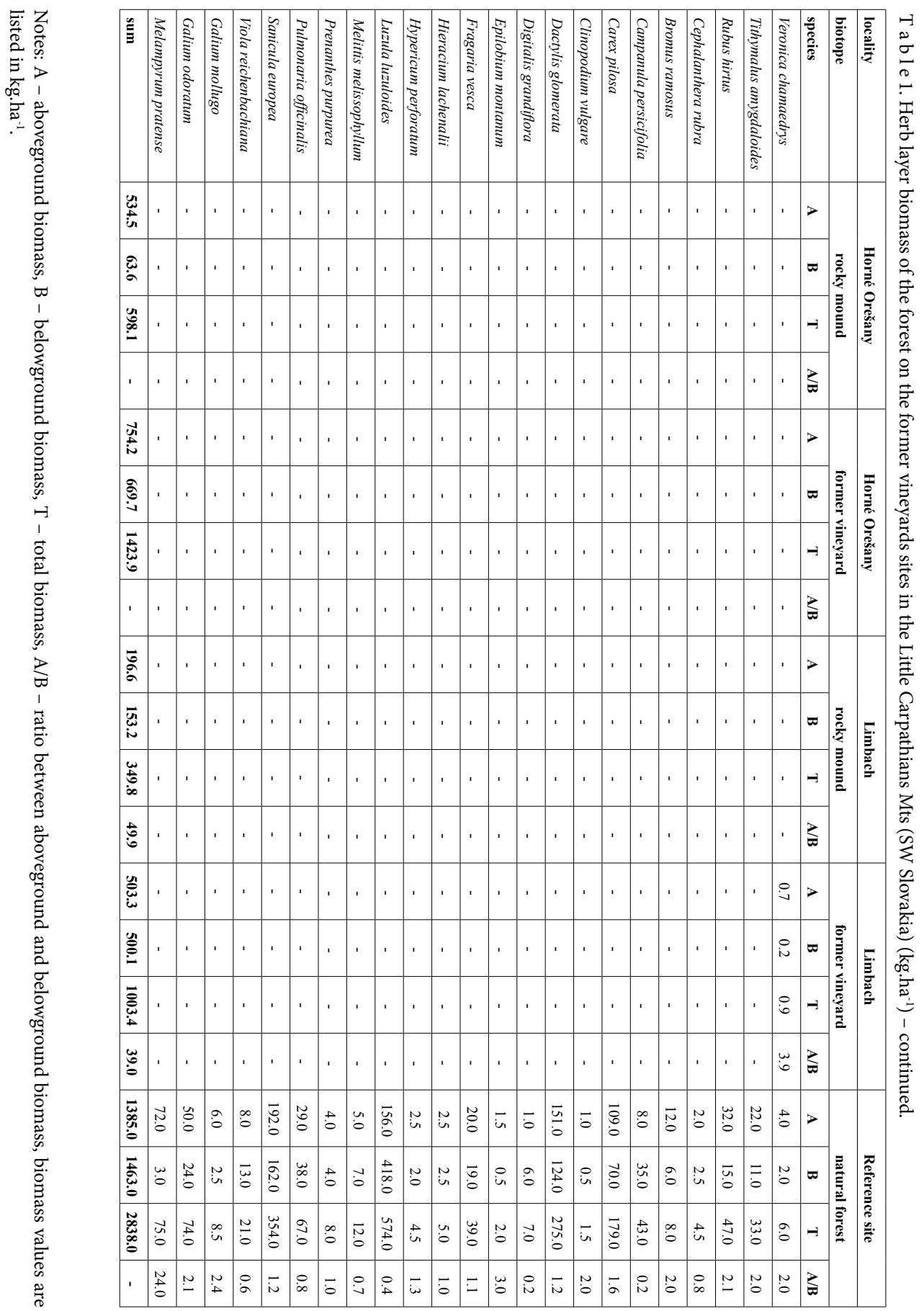




\section{Comparison with other oak-hornbeam forests}

The herb layer biomass estimated on the observed sites is vividly lower than that on the reference site. However, when comparing our results with those from other oak-hornbeam forests from western Slovakia (Table 2) obtained by the same method, there is no statistically significant evidence (at $\mathrm{P}=0.05$ ) to prove that the aboveground biomass in the forests on the former vineyards is lower than that of the original forests, except for the old oak forest on the rocky

$\mathrm{T}$ a $\mathrm{b}$ l e 2. Herb layer biomass of the original data and some oak-hornbeam forests in the western Slovakia and results of the exact binomial test to prove whether the aboveground biomass in forests on former vineyards is lower than the aboveground biomass in reference forests.

\begin{tabular}{|c|c|c|c|c|c|c|c|}
\hline Author(s) & Locality & $\begin{array}{l}\text { Vegetation } \\
\text { type }\end{array}$ & $\begin{array}{c}\text { A } \\
{\left[\mathrm{kg} \mathrm{ha}^{-1}\right]}\end{array}$ & $\begin{array}{c}\text { B } \\
{\left[\mathrm{kg} \cdot \mathrm{ha}^{-1}\right]}\end{array}$ & $\begin{array}{c}\mathrm{T} \\
{\left[\mathrm{kg} \cdot \mathrm{ha}^{-1}\right]}\end{array}$ & P-value & $\begin{array}{l}\text { S at } \\
0.05\end{array}$ \\
\hline Kubíček, Jurko (1975) & $\begin{array}{l}\text { Little } \\
\text { Carpathians } \\
\text { Mts. }\end{array}$ & $\begin{array}{l}\text { Carici pilosae- } \\
\text { Carpinetum } \\
\text { (dominated by } \\
\text { Melica uniflora) }\end{array}$ & 690 & no data & no data & - & - \\
\hline $\begin{array}{l}\text { Kubíček, Šimonovič } \\
\text { (1975) }\end{array}$ & $\begin{array}{l}\text { Nitrianska } \\
\text { pahorkatina }\end{array}$ & $\begin{array}{l}\text { Oak-hornbeam } \\
\text { forest }\end{array}$ & 429 & 274 & 703 & - & - \\
\hline $\begin{array}{l}\text { Kubíček, Šimonovič } \\
\text { (1980) }\end{array}$ & $\begin{array}{l}\text { Little } \\
\text { Carpathians } \\
\text { Mts. }\end{array}$ & $\begin{array}{l}\text { Carici pilosae- } \\
\text { Carpinetum }\end{array}$ & 1380 & 1460 & 2840 & - & - \\
\hline $\begin{array}{l}\text { Šomšák, Kubíček } \\
\text { (1995) }\end{array}$ & $\begin{array}{l}\text { Borská nížina } \\
\text { lowland }\end{array}$ & Melico-Tilietum & 360 & & & - & - \\
\hline Kollár et al. (2009) & $\begin{array}{l}\text { Biele Karpaty } \\
\text { Mts }\end{array}$ & $\begin{array}{l}\text { Carici pilosae- } \\
\text { Carpinetum } \\
\text { melicetosum }\end{array}$ & 750 & 905 & 1655 & - & - \\
\hline Kollár et al. (2010) & $\begin{array}{l}\text { Chvojnická } \\
\text { pahorkatina }\end{array}$ & $\begin{array}{l}\text { Carici pilosae- } \\
\text { Carpinetum } \\
\text { typicum }\end{array}$ & 431 & 510 & 941 & - & - \\
\hline Original data & $\begin{array}{l}\text { Little } \\
\text { Carpathians } \\
\text { Mts., Horné } \\
\text { Orešany }\end{array}$ & $\begin{array}{l}\text { Yonger ash for- } \\
\text { est on the rocky } \\
\text { mound }\end{array}$ & 534.49 & 63.61 & 598.11 & 0.062 & no \\
\hline Original data & $\begin{array}{l}\text { Little } \\
\text { Carpathians } \\
\text { Mts., Horné } \\
\text { Orešany }\end{array}$ & $\begin{array}{l}\text { Younger ash } \\
\text { forest on the } \\
\text { former vine- } \\
\text { yard }\end{array}$ & 754.24 & 669.7 & 1423.91 & 0.665 & no \\
\hline Original data & $\begin{array}{l}\text { Little } \\
\text { Carpathians } \\
\text { Mts., } \\
\text { Limbach }\end{array}$ & $\begin{array}{l}\text { Old oak forest } \\
\text { on the rocky } \\
\text { mound }\end{array}$ & 196.6 & 153.2 & 349.8 & $<0.01$ & yes \\
\hline Original data & $\begin{array}{l}\text { Little } \\
\text { Carpathians } \\
\text { Mts., } \\
\text { Limbach }\end{array}$ & $\begin{array}{l}\text { Old oak forest } \\
\text { on the former } \\
\text { vineyard }\end{array}$ & 503.28 & 500.11 & 1003.39 & 0.062 & no \\
\hline
\end{tabular}

Abbreviations: A - aboveground biomass, $\mathrm{B}$ - belowground biomass, $\mathrm{T}$ - total biomass, $\mathrm{S}$ - significance. 
mound. Also, except for the aforementioned site, the values we estimated fall within the interval found for the natural oak-hornbeam forests.

\section{Conclusion}

When answering the question of impact of the historical vineyard land use on the productivity of the contemporary forest herb layer, the following can be concluded: the former land use modified original relief, where the former vineyards have modified soil profile and new relief forms-rocky mounds-were created. These mounds with no or just shallow soils are usually much less covered by vegetation; thus, the production of herb layer biomass is lower here than in the adjacent former vineyards. Moreover, rocky mounds show a higher ratio of synanthropic species and apophytes than the adjacent former vineyards, and same as for the ratio of therophytes. The younger the stands on the former vineyards, the higher is the ratio of synanthropic species, apophytes, and therophytes. On the other hand, when estimating the production quantity, the values of herb layer production on the former vineyards are similar to those in the natural oak-hornbeam forests found in the Little Carpathians Mts. and the adjacent regions, except for rocky mounds covered by the old oak forests, which are less productive. In other words, the former vineyard land use affects the herb layer production quality, rather than the quantity.

\section{Acknowledgements}

This contribution was financially supported by VEGA grant No. 2/0016/15.

\section{References}

Braun-Blanquet, J. (1964). Pflanzensoziologie. Grundzüge der Vegetationskunde. Wien: Springer-Verlag.

Dlapa, P., Chrenková, K., Hrabovský, A., Mataix-Solera, J., Kollár, J., Šimkovic, I. \& Juráni B. (2011). The effect of land use on the soil aggregate stability in the viticulture district of Modra (SW Slovakia). Ekológia (Bratislava), 30(4), 397-404. DOI: 10.4149/ekol_2011_04_397.

Fusán, O. (1972). Geology (in Slovak). In M. Lukniš et al. (Eds.), Slovensko 2. Príroda (pp. 19-123). Bratislava: Obzor.

Jurko, A. (1990). Ecological and socio-economic evaluation of vegetation (in Slovak). Bratislava: Príroda.

Kolény, M. (2001). Anthropogenic soils of Modra town. Proceedings of the Soil Anthropization VI (pp. 102-104). Bratislava: Soil Science and Conservation Institute.

Kollár, J., Kubíček, F., Šimonovič, V. \& Kanka R. (2009). Herb layer biomass of some broadleaved forest ecosystems near Skalica (Biele Karpaty Mts). Ekológia (Bratislava), 28(3), 225-233. DOI: 10.4149/ekol_2009_03_225.

Kollár, J., Kubíček, F., Šimonovič, V., Kanka, R. \& Balkovič J. (2010). Production-ecological analysis of the broadleaved forest ecosystems herb layer biomass in the Žalostínska vrchovina upland and Zámčisko (western Slovakia). Ekológia (Bratislava), 29(2), 113-120. DOI: 10.4149/ekol_2010_02_113.

Kubíček, F. \& Brechtl J. (1970). Production and phenology of the herb layer in an oak-hornbeam forest. Biológia (Bratislava), 25, 651-666.

Kubíček, F. \& Jurko A. (1975). Estimation of above-ground of the herb layer in forest communities. Folia Geobot. Phytotax., 10, 113-129.

Kubíček, F. \& Šimonovič V. (1975). Dynamics and phenology of the total biomass of the herbaceous layer in two forest communities. Biológia (Bratislava), 30,: 505-522.

Kubíček, F. \& Šimonovič V. (1980). The total herb layer biomass in several less presented forest communities in the Malé Karpaty Mountains. Biológia (Bratislava), 35, 27-38.

Kubíček, F. \& Šomšák L. (1982). The herb layer production of fir forests in the eastern part of the Slovenské rudoho- 
rie Mountains. Biologické Práce, 28, 52-178.

Lapin, M., Faško, P., Melo, M., Štastný, P. \& Tomlain J. (2002). Map of climatic regions 1 : 1000000 (in Slovak). In Atlas krajiny Slovenskej republiky (p. 95). Banská Bystrica: SAŽP.

Lukniš, M. (1972). Relief (in Slovak). In M. Lukniš et al. (Eds.), Slovensko 2. Príroda (pp. 124-160). Bratislava: Obzor.

Marhold, K., Goliašová, K., Hegedüšová, Z. et al. (1998). Fern and flowering plants (in Slovak). In K. Marhold \& F. Hindák (Eds.), Checklist of nonvascular and vascular plants of Slovakia (pp. 333-687). Bratislava: Veda, vydavatel'stvo SAV.

Michalko, J., Berta, J. \& Magic D. (1986). Geobotanical map of ČSSR. Slovak Socialistic Republic (in Slovak). Text part and maps. Bratislava: Veda, vydavatel'stvo SAV.

Slavkovský, P. (2002). Agrarian culture in Slovakia - Change over time (in Slovak). Bratislava: Veda, vydavatelstvo SAV.

Šomšák, L. \& Kubíček F. (1995). Phytocoenological and production evaluation of the original and secondary pine forests of the Záhorská nížina lowland. II. Alliance Carpinion (Melico uniflorae-Tilietum cordatae ass. nova hoc loco). Ekológia (Bratislava), 14, 247-259.

Záruba, F. (1985). Viticulture. Bratislava: Príroda.

Zima, L., Kollár, J., Rišková, A. \& Balkovič J. (2015). Phytocoenological characteristics of the Malé Karpaty Mts. forest on the sites of former vineyards (in Slovak). Phytopedon, 14, 25-37. 